\title{
A CASE STUDY ON GLASS CEILING SYNDROME OF FEMALE EMPLOYEES IN THE INFORMATION TECHNOLOGY SECTOR*
}

\author{
İbrahim YILDIZ** \\ Hatice Nur YILDIZ ${ }^{* * *}$ \\ Fatma ARSLAN ${ }^{* * * *}$
}

\begin{abstract}
Glass ceiling syndrome is a sex-based obstacle that female employees encounter while they advance in their career. This syndrome should not be perceived only as an obstacle in the path of hierarchical progression. Glass ceiling syndrome can also manifest itself in the attitudes that may lead to income inequality and negative effects on prestige. The glass ceiling syndrome can result from the individual circumstances of women as well as from the perceptions and attitudes which are raised by some social dynamics within the organizational structure. Moreover, special roles for women and men in some occupational groups are one of the social factors which include glass ceiling syndrome. In this context, Information Technologies (IT) sector should also be investigated. In this study, the following questions are clarified: "Is the IT sector a male-oriented sector? Which factors cause glass ceiling that women in the IT sector may face? How can the real value of female employees be measured for the IT sector?". In this context, the opinions of full-time and part-time employees in the information sectors and of the academics from the Department of Management Information Systems, training personnel for the IT sector, will be asked. To achieve this, both the questionnaire and semi-structured interviews were conducted. As a result, it was seen that there is a prejudice against the female employees in the IT sector. Especially, it was suggested by men that female employees will struggle in the IT sector, whereas women claimed that they are successful enough. Male and female academics have different opinions about the failure of female students and male academics attribute this failure to gender factor. Male experts in IT sectors are less prejudiced against women than male academics. The findings of the study will also be significant contribution to the research questions in future studies in this field.
\end{abstract}

Keywords: Glass Ceiling Syndrome, IT Sector, Female Employees.

\section{BİLIŞi̇M TEKNOLOJILERI SEKTÖRÜNDEKİ KADIN ÇALIŞANLARIN CAM TAVAN SENDROMU ÜZERINE BIR DURUM ARAŞTIRMASI}

\section{ÖZET}

Cam tavan sendromu, kadınların kariyerlerinde ilerlerken karşılaştıkları cinsiyete dayalı engellerdir. Cam tavan sendromu, sadece hiyerarşik ilerlemenin önündeki bir engel olarak algılanmamalıdır. Cam tavan sendromu aynı zamanda, gelir eşitsizliği ve prestij üzerindeki olumsuz etkilerin ortaya çımasına neden olabilecek tutumlarda da kendini gösterebilir. Cam tavan sendromunun nedenleri, kadınların

* This article is full text of poster presentation in IWSC IWSC International Conference on Contemporary Women's Studies March 08-09 2018 İstanbul.

* Arş. Gör. Atatürk Üniversitesi, İktisadi ve İdari Bilimler Fakültesi Yönetim Bilişim Sistemleri Bölümü, ibryildiz@atauni.edu.tr

** Arş. Gör. Atatürk Üniversitesi, İletişim Fakültesi, Halkla İlişkiler ve Tanıtım Bölümü, haticenur. yildiz@atauni.edu.tr

Yükssek Lisans Öğrencisi, Atatürk Üniversitesi, İktisadi ve İdari Bilimler Fakültesi Yönetim Bilişim Sistemleri Bölümü. 
bireysel koşullarından ileri gelebileceği gibi, örgütsel yapı içerisindeki bazı sosyal dinamiklerin beslediği alg1 ve tutumlardan da beslenebilir. Ayrıca, bazı meslek gruplarında kadınlara ve erkeklere verilen özel roller, cam tavan sendromunu etkileyen sosyal faktörlerden biridir. Bilişim Teknolojileri (BT) sektörü de bu bağlamda araştırılmalıdır. Bu çalışmada şu sorular açıklığa kavuşturulmaktadır: BT sektörü erkeklere yönelik bir sektör müdür? BT sektöründe ilerlemek isteyen kadınların karşılaşabileceği cam tavan engeli hangi faktörlerle ilerlemektedir? BT sektörü için kadın çalışanların gerçek değeri nasıl ölçülebilir? Bu bağlamda, bilişim sektöründe çalışan tam zamanlı çalışanların, yarı zamanlı çalışanların ve bilişim sektörüne yönelik personel yetiştirmeyi amaçlayan yönetim bilişim sistemlerindeki akademisyenlerin görüşlerine başvurulmuştur. Bunun için hem anket uygulaması yapılmış hem de yarı yapılandırılmış bire bir görüşmeler gerçekleştirilmiştir. Sonuç olarak; BT sektöründe kadın çalışanlara karşı bir önyargı olduğu görülmektedir. Özellikle erkekler tarafından kadın işçilerin BT sektöründe zorlanacakları öne sürülürken, kadınlar ise yeterince başarılı olduklarını ileri sürdükleri görülmüştür. Erkek ve kadın akademisyenlerin kız öğrencilerin başarısızlığı hakkında farklı görüşleri olduğu ve erkek akademisyenlerin bu başarısızlığı cinsiyet faktörüne bağladıkları görülmüştür. Bilişim sektöründeki erkek uzmanların erkek akademisyenlere göre kadınlara karşı daha az önyargılı olduğu görülmüştür. Çalışmanın bulguları, gelecekte bu alanda yapılacak çalışmalarla ilgili araştırma soruları için de çok önemli bir katkı niteliktedir.

Anahtar Kelimeler: Cam Tavan Sendromu, Bilişim Sektörü, Kadın Çalışanlar

\section{INTRODUCTION}

In the literature research of the work, the coverage of glass ceiling syndrome and its dimensions were clarified. The key aspects regarding glass ceiling syndrome in literature are found as follows (Akpınar-Sposito, 2012; Coleman, 2010; Cotter et al., 2001; Erdirençelebi \& Karakuş, 2018; Jackson \& O’Callaghan, 2009; Johns, 2013; Liff \& Ward, 2001; Lockwood, 2004; Sinha \& Sinha, 2011; Smith, 2012; Wright \& Baxter, 2000):

- Glass ceiling syndrome was introduced in the United States in the 1970s, but the it was first used in entitled "Women in Business" article in Wall Street Journal in 1986.

- Glass ceiling syndrome can be seen in different sectors in different countries. It is not a problem for a particular business sector and a particular country.

- Glass ceiling is a situation that most faced by women who attempt or aspire to attain senior positions in corporations, government, education and nonprofit organizations.

- Glass ceiling syndrome occurs with invisible obstacles in front of career planning. These obstacles can manifest themselves from the choice of profession which is desired in career advance to all stages made until reaching the top of the hierarchy.

- Glass ceiling can stand in the way of vested interests of the person having a profession and can harm the occupational prestige of the victim.

- The glass ceiling is not just for women. It also applies to minorities in the profession or workplace. (The fact that women are also a minority in the IT 
sector is important in this context.)

- Glass ceiling syndrome has no rational basis.

- Glass ceiling syndrome increases.as the victim earns more

- In order to overcome the glass ceiling syndrome, it is necessary to make efforts at the individual, institutional and social levels. It should not be forgotten that governments also play an important role here.

- Glass ceiling is gender and racial inequality regardless of professional performances. It is used for racial and ethnic minorities.

- The factors causing the formation of glass ceiling syndrome; it is classified as individual, organizational and social factors. Individual factors: They include work-family conflict, multiple roles, personal preference and perceptions of women. Organizational factors: They include obstacles such as organizational culture, organizational policies, lack of mentor. Due to the fact that management culture is created by men, management is seen as difficult job, so it is thought that women do not have the necessary features for the job. In order to be successful in management, it is necessary to spend longer time at work, and this situation prevents the balance of work and family life. Social factors: They include prejudices and stereotypes. The patriarchal structure determines different gender patterns and roles for men and women. Men are effective in decisions. It is thought that women's features such as emotional, passive and collaborative are an obstacle to upper stages.

In the second stage of the literature research, the aspects of the IT sector, related to this subject were examined and important conclusions reached are as follows (Ferencikova \& Hluskova, 2015; Golden-Sanchez, 2012; Leng, 2017; Panibratov \& Latukha, 2014; Peterson, 2005):

- IT sector is interested in lines of business which contain telecommunication-network, software, hardware, after-sales services-system integration, $\mathrm{R} \& \mathrm{D}$ and technology development activities.

- The information sector means a turbulent environment because IT sector provide a basis of dazzling rapid progress for information. Therefore, the institutions in this sector have to operate in a very dynamic and turbulent environment. To achieve this, institutions should be able to develop their own resources, to retain know-how information and to protect them so that they can maintain their stability. State-governments should make the necessary arrangements for their own countries. For example, Taiwan decided to build its own Silicon Valley. The IT sector is a sector, where labor and employee can face difficulties. When it is taken care of and that legislation of EPL, which is an important criterion by OECD is given up, it is clear that the human resources in this sector will be highly depressed and inevitably be faced with injustice. For this reason, the situation of the female employees who are members of a minority group and victims in IT sector should 
be investigated.

- In successful IT institutions, it is emphasized that relationships with customers, the nature of the institution's human resources management, and the importance of technology ownership are very important. On the other hand, the most important factor in the success of successful institutions is to employ qualified employees. This contradictory situation reveals the pathetic state of the qualified staff in this sector.

\section{EXPERIMENTAL WORK}

In the practice part of the study, both semi-structured interview which is one of qualitative research techniques, and a questionnaire were also implemented. One-to-one interviews were conducted with senior managers working in the information sector and academics from the Department of Management Information Systems and the Informatics Institute (Atatürk University and Istanbul University). In the survey, 36 IT staff members who were employed in the group in women IT specialists.

In the qualitative research part of the study, questions were prepared according to the main points that became apparent in the context of literature review. Some questions such as What is the importance of women in terms of information sector? Do you think that women have difficulty in IT sector? Do you think that women have a lack of self-confidence? Do you think that the social roles of women negatively affect their career in the information sector? were used the qualitative side of the research.

In the quantitative part of the study, the questionnaire method was used. For this, surveys were applied to the employees who work at the Atatürk University Information Technology Center and IT specialists who work in various private and public institutions. 36 people participated in the survey. In the study, the scale which was used by Smith, Crittenden \& Caputi (2012) was used. SPSS 20 program was used for the analysis of research data.

\section{Participants}

The great majority of the participants in the survey were man. The most of the participants were young people who have worked in IT sector for 5 years or less. Table 1.1. includes demographic information of the participants. 
Table 1.1. Demographic Variables

\begin{tabular}{|l|c|c|}
\hline Demographic Variables & $\mathrm{N}$ & $\%$ \\
\hline Man & 28 & 77,8 \\
\hline Woman & 8 & 22,2 \\
\hline $20-25$ age & 20 & 55,6 \\
\hline 26-30 age & 11 & 30,6 \\
\hline $31-40$ age & 4 & 11,1 \\
\hline 41 year-old and over & 1 & 2,8 \\
\hline People who have been working for 1-5 years & 27 & 75 \\
\hline People who have been working for 6-10 years & 5 & 13,9 \\
\hline 11 years and over & 4 & 11,1 \\
\hline Full time employees & 27 & 75 \\
\hline Part-time employees & 9 & 25 \\
\hline Married & 6 & 16,7 \\
\hline Single & 30 & 83,3 \\
\hline Employees in the public sector & 8 & 22,2 \\
\hline Employees in the private sector & 28 & 77,8 \\
\hline Software developers & 17 & 47,2 \\
\hline Hardware experts & 3 & 8,3 \\
\hline Interested in web design & 8 & 22,2 \\
\hline Interested in system security & 2 & 5,6 \\
\hline Interested in database & 6 & 16,7 \\
\hline
\end{tabular}

In-depth interviews were conducted with 20 participants in order to learn the glass ceiling syndromes of female employees in IT sector. Questions were prepared considering the literature on the subject. Six questions were asked about this subject to participants. Interviews were conducted with academicians and experts working in the IT sectors. Eleven participants are man and nine participants are woman. Seven male and three female participants are academicians and four male and six female participants are experts. The participants were asked the following questions:

- Do you agree that the IT sector is a male-dominated sector?

- Why women are important in this sector?

- How are girl students' academic achievement levels?

- Do you agree that women are alienated in this sector?

- Do women's social roles have a negative effect on their careers?

- In which field are women working in the IT sector successful?

The answers to the questions were recorded both in voice recording and in writing. 


\section{FINDINGS}

As a result of the qualitative research technique of the study, the findings obtained from the opinions of the experts doing academic studies in the field of information are as follows:

- Academics agree that information sector is a male-dominated sector. But, according to them, the reason for this may be that women do not show interest in the information sector. In particular, it is emphasized that IT specialists who are in today's business world were in connection with computer games which were for boys.

- The presence of women in the information sector solves the problems caused by the lack of emotion and tolerance in the sector. It helps to acquire different viewpoints and aesthetic feelings in information, so communication between human and information can be easier. According to some male academics, due to the fact that women have difficulty in information sector the presence of women in information sector is unnecessary.

- According to male academics, the success of female students in IT education is low in the field of software and algorithm development. Female academics do not agree with this view and indicate that success can be explained by individual factors. Some of the male academics point out that women are not sufficiently encouraged in the information-oriented education programs.

- According to academics, there are absolutely prejudices and disdain for the women in the field of information; but the presence of women in information sector cannot be prevented. It is also possible to overcome this negative attitude with individual efforts.

- According to the male academics, the roles that are imposed on women (such as being a mother, being a wife) definitely affect the success of women in the information sector. Women academics do not accept in this view.

- While male academics have suggested that women may exist in the aesthetic part of the information sector such as graphic design, women academics believe that success must be assessed individually and that successful women entrepreneurs can be in all business lines of information.

As a result of the qualitative research carried out interviews with experts in IT sector:

- The information sector used to be regarded as a male dominant sector but today, there is no longer any validity to make a limitation in this sense because this sector is a sector where knowledge is at the forefront.

- In the information sector, the employment of women and the prominence of the women's leadership will lead to different perspectives and sense of aesthetic. This will make communication between human and information easier. 
- According to male experts, there is no emotion in the information sector. Therefore, successful women IT specialists make a lot of effort.

- Women IT specialists are excluded in the information sector and the lack of women specialists in the information sector can require depth analysis.

- While the various social roles given to women (such as being a mother, being a wife) are not an obstacle according to women IT specialists and academics, they are obstacles for male IT specialists and academics.

- Married women argue that women are more successful in the non-technical parts of information, while single women also say that women will also be successful in the technical part of the information (such as software). Man IT specialists who operate in the sector do not limit women to specific areas.

The results of the in-depth interview are as follows:

- Do you agree that the IT sector is a male-dominated sector?

All academics answered yes. Some answers of academics are as follows:

M. "I agree. The IT sector should be the male dominant sector. The IT sector is not for women."

F. "Unfortunately, I agree with this idea."

M. "Yes, but women's low interest in the IT sector is effective."

F. "I agree"

When the answers are analyzed, it is seen that all of the male and female academics have the idea that the IT sector is a male dominated sector.

Some answers of experts are as follows:

F. "I agree"

M. "Knowledge and ability are important. I do not agree this idea."

F. "This thought has changed. Women also became active in IT sector."

M. "I agree, but this thought can be changed"

When the answers are analyzed, according to most experts, IT sector is a male-dominated sector but knowledge and ability are important.

- Why women are important in this sector?

Some answers of academics are as follows:

F. "Diversity enhances the dynamism and efficiency."

M. "Women in the IT sector is not important. Female employees in the IT sector do not adapt to the system."

F. "Women can bring emotional intelligence and creative solutions to this sector."

M. "I think that women do not have any importance and contribution to the IT sector except for some issues such as marketing."

M. "With the inclusion of women in IT, an evaluation from different per- 
spectives can be made especially in the field of human-computer interaction."

M. "The fact that women are in the IT sector reduces the lack of feelings and tolerance."

When the answers are analyzed, it is seen that women are supported in IT sector, but academics think that women should be in IT sector for design, order etc. rather than technic subjects.

Some answers of experts are as follows:

F. "Women are important in every sector. Women are more successful in communicating."

F. "If there are women in the IT sector, there are different perspectives."

M. "Women should be in every field because women can find alternative solutions to problems."

M. "Women should work in the informatics sector in order not to be alienated from society."

When the answers are analyzed, it is seen that experts agree that women should work in IT sector.

- How are female students' academic achievement levels?

Most of the participants think that male students are more successful. Some answers of academics are as follows:

F. "Algorithmic thinking skills are associated with interest."

M. "Female students are not successful in algorithm and software. I've been studying software for many years. I think women are not successful in developing algorithms."

M. "I don't think women have much talent in algorithmic thinking."

F. "Female students and male students are equally successful."

M. "In today's education system, women are not encouraged in the informatics sector. In a male-dominated educational environment, women can feel themselves foreign, so girls are not successful more than men."

When the answers are analyzed, according to participants, male student are more successful than female students. Especially, male participants think that female are not successful in technical subject such as algorithm and software.

- Do you agree that women are alienated in this sector?

Some answers of academics are as follows:

M. "Due to the fact that women are emotional, the heavy working conditions of the IT sector may not be for women. In this context, they may feel excluded in the sector." 
M. "There's definitely a prejudice against women."

M. "Yes"

When the answers are analyzed, male participants agree that women are excluded in IT sector.

Some answers of experts are as follows:

M. "I do not agree"

F. "I do not think like this."

When the answers are analyzed, all of experts do not agree this idea. According to them, women are not excluded in the IT sector.

- Do women's social roles have a negative effect on their careers?

Some answers of academics are as follows:

F. "Never"

F. "I do not agree"

M. "It definitely has a negative effect"

M. "The duties and responsibilities of married women have a negative effect on the IT sector"

M. "Social roles have a negative effect, for example when women are on maternity leave, they can't come to work for a long time."

When the answers are analyzed, male participants think that women's social roles have a negative effect, but female participants do not agree the idea.

Some answers of experts are as follows:

M. "There are many prejudices against women. Women can be both mother and businesswoman."

M. "Maternity leave can be a negative effect but generalization cannot be made."

F. "Social rules can affect in negative way."

When the answers are analyzed, experts do not think that women's social rules have negative effect on their careers.

- In which field are women working in the IT sector successful?

Some answers of academics are as follows:

F. "They are successful in every field."

M. "They may be successful in non-technical fields, such as design, customer relations, etc."

M. "They are more successful in project management but fail more in basic tasks such as coding."

M. "I think that they can create unique things especially in the field of design. There is no specific area to fail." 
When the answers are analyzed, it is seen that women are not more successful in technical fields for male participants.

Some answers of experts are as follows:

M. "The success is not related to gender. Experience and knowledge are important."

M. "Women are successful in every field."

F. "Women are successful in every field where they want."

When the answers are analyzed, it is seen that experts do not restrict specific area for women.

\section{DISCUSSION AND CONCLUSIONS}

As a result of the survey, the following findings were reached:

- According to the results of the survey, it is also seen that there is a barrier to the women in the information sector. But according to the general opinion of some male participants, this obstacle is the natural consequence of women's social roles and women's distance to knowledge. On the other hand, a large proportion of the survey participants believe that if women are given sufficient opportunities, they will be able to overcome the obstacles. Indeed, according to the participants at a certain level, obstacles for women gradually decrease.

- As a result of the questionnaire application, according to the IT specialists working in the field of programming and software, the glass ceiling to women is more evident, but according to the IT specialists working in the field of web design, the glass ceiling is not more evident. This finding supports the idea that women can express themselves better at certain stages of information, as some experts and academics have pointed out in qualitative research results.

- Another result of the survey is that single people have more feminist perspective than married people. Married participants acknowledge that there is glass ceiling for women in IT sector and express that the obstacle should not be exaggerated because they believe if they wish and have necessary opportunities, they will overcome the obstacle. On the other hand, it is understood that single IT specialists are more emotional and they accept the obstacles more clearly.

When the findings obtained in the study were evaluated, it is important to know that the research was carried out in a very limited field, therefore the evaluations cannot be generally attributed. But it should be taken into consideration that the research on this subject in the information sector is also very limited, so the study can be developed. In this respect, conclusions and evaluations are significant. 
The findings obtained in this study, in which both quantitative and qualitative research techniques were applied, present the following points: It is clear that the information sector is a male-dominated sector. However, this situation causes the IT sector to be deprived of the woman's perspective. At this point, it will be useful to understand the reason why women are excluded in the IT sector. In this sense, it is obvious that it will be important to examine the factors that determine the relationship of girls to their computers, especially digital games. Man academics already believe that the presence of people who were born in the 1980s in the business world today has turned the sector to a male-dominated one.

It is understood that there is a common belief that women's employment in the IT sector will not make a significant difference. Especially male academics argue that women cannot keep up with the IT sector; but women specialists and academics say that they can be successful in IT sector if they want it. In this context, according to both academics and experts, men decide without considering women's ideas. It is understood that for women's employment in the IT sector, the collaboration of women is important.

The great majority of male academics agree that there are no emotions in IT sector and women should deprive themselves in order to success in this sector. Does an individual who really wants to be successful in the IT sector have to get rid of his/her emotional and sensitive feelings? Can't women's aesthetics be found in IT sector? Field research can be done in order to answer these questions. When it is observed that the views of academics are more unflexible than the views of the free market experts, it is concluded that the manners and attitudes of the universities should be discussed again.

\section{QUESTIONS AND SUGGESTION FOR FUTURE RESEARCH}

As a result of this study, the following questions come to mind. At the same time, these questions can be suggested for future studies.

- How can performance assessment in IT sector be made fairer?

- Are there not emotions in IT sector?

- What are the roles of female specialists in the information sector and the effects of appropriate business lines on information?

- Why does not IT change and transform emotions and thoughts of academics, IT producers and managers although IT can change all society's segments?

- What is the relationship between digital games and girls?

- Why are academics biased against women working in the field information? 


\section{REFERENCES}

Akpinar-Sposito. (2012), "Career barriers for women executives and the Glass Ceiling Syndrome: the case study comparison between French and Turkish women executives" Procedia - Social and Behavioral Sciences, 00-000.; https://halshs. archives-ouvertes.fr/halshs-00738519/document.

Coleman, I. (2010), 'The Global Glass Ceiling: Why Empowering Women Is Good for Business", Foreign Affairs, 89 (3), 13-20.

Cotter, D. A., Hermsen, J. M., Ovadia, S. \& Vanneman, R. (2001). “The Glass Ceiling Effect", Social Forces, 80 (2), 655-681.

Erdirençelebi, M., Karakuş, G. (2018). "Kadın Çalışanların Cam Tavan Sendromu Algıllarının İş Tatminleri ve Örgütsel Bağlılıkları Üzerindeki Etkisini Ölçmeye Yönelik Bir Araştırma”, İşletme Araştırmaları Dergisi, 10(3), 95-119.

Ferencikova, S. \& Hluskova, T. (2015), ' Internationalization of Central and Eastern European Companies Theory and Its Implications in The Slovak IT Sector", Journal of East European Management Studies, 20 (4), 415-434.

Golden-Sanchez, J. E. (2012), ' Employment Protection Legislation and the IT-Sector in OECD Countries", Recherches Économiques de Louvain / Louvain Economic Review, 68 (1/2), 169-184.

Jackson, J. F. L. \& O'Callaghan (2009), ' What Do We Know About Glass Ceiling Effects? A Taxonomy and Critical Review to Inform Higher Education Research", Research in Higher Education, 50 (5), 460-482.

Johns, M. L. (2013). "Breaking the Glass Ceiling: Structural, Cultural, and Organizational Barriers Preventing Women from Achieving Senior and Executive Positions", Perspectives in Health Information Management, Winter 2013, 1-11.

Leng, T. (2017), Cross-Strait Economic Relations and China's Rise: The Case of the IT Sector, Dittmer, L., Taiwan and China-Fitful Embrace, University of California Press.

Liff, S. and Ward, K., (2001). "Distorted Views Through the Glass Ceiling: The Construction of Women's Understandings of Promotion and Senior Management Positions", Gender, Work and Organization, 8(1), 19-36

Lockwood, N. (2004). "The Glass Ceiling: Domestic and International Perspectives", Research Quarterly, 1-10; http://avconline.avc.edu/bbeyer/Bb_WIO_ Articles/Ch2_A/GlassCeiling_DomesticAndInternational_2004.pdf

Panibratov, A. \& Latukha, M. (2014), " Obtaining international results through partnerships: evidence from

Russian MNEs in the IT sector", Journal of East European Management Studies, 19 (1), 31-57.

Peterson, D. J. (2005), The IT Sector, Russia and The Information Revaluation, RAND Corporation. 
Sinha, U. P. \& Sinha, D. (2011). "Are Indian women scientists victims of the 'glass ceiling'?", Current Science, 100 (6), 837-840.

Smith, P., Crittenden, N. \& Caputi, P. (2012). ' Measuring Women's Beliefs About Glass Ceilings: Development of the Career Pathways Survey", Gender in Management, 27 (2), 68-80.

Smith, R. A. (2012). "A Test of the Glass Ceiling and Glass Escalator Hypotheses", The Annals of the American Academy of Political and Social Science, 639, 149172.

Wright, O. E. \& Baxter, J. (2000). 'The Glass Ceiling Hypothesis: A Reply Critics", Gender and Society, 14 (6), 814-821. 
